\title{
Exploring the Role of Dark Tourism in the Creation of National Identity of Young
}

Americans

\author{
Julie S. Tinson
}

Michael A. J. Saren

Bridget E. Roth

Julie S. Tinson, Marketing and Retail Division, Stirling Management School, University of Stirling, Stirling, Scotland, UK, Email: j.s.tinson@stir.ac.uk, Phone: +44 (0) 1786467389 , Fax: $+44(0) 467400$

Michael A. J. Saren, School of Management, University of Leicester, Leicester, UK, Email: majs1@le.ac.uk, Phone: +44 (0) 1162231011

Bridget E. Roth, Marketing and Retail Division, Stirling Management School, University of Stirling, Stirling, Scotland, UK

Please address all communication about this article to Julie Tinson.

Email: j.s.tinson@stir.ac.uk, Phone: +44 (0) 1786 467389, Fax: +44 (0) 467400 


\section{Biographies:}

Julie Tinson is Professor of Marketing at the University of Stirling where she principally teaches Consumer Behaviour and Marketing Management. Her research interests are motivated by an interest in the relative impact of transition on consumption and identity formation using ritual practice as a context. Publications have centred on the interrelationships between adolescent consumer behaviour and the social factors that affect the consolidation of identity positions.

Michael Saren is Professor of Marketing at the University of Leicester. His interests include Marketing Theory, Critical Marketing, Consumer Research as well as Technology and Marketing. His recent research projects have investigated identity performances and gender expressions at the Whitby Goth festival, the privatized space of Starbucks and co-editing a special edition of the JMM on Marketing in Virtual Worlds

Bridget Roth is a specialist in Tourism Marketing with a particular interest in Dark Tourism. 
Abstract: The purpose of this paper is to examine the role of dark tourism in constructing narratives and stories which co-create and reinforce national identity. By focusing on the voice of the tourist and their consumer experience, we develop an understanding of youth behaviours and motivations associated with dark tourism and the effect of social influences in forming narratives. This empirical study comprises 20 interviews with young American dark tourist site visitors, 11 of whom were re-interviewed. The emic insights suggest dark tourism experiences can be used to (re)affirm individual roles, enhance feelings of national identity and co-create a self as well as a national identity. An etic conceptual model is proposed that is specifically designed for dark tourism sites. It provides a novel explanation of national identity co-creation and recognises the relationship between tourist motivation, experience and co-creation.

Keywords: Co-creation, National Identity, Dark Tourism, Narratives, Youth

Summary statement of contribution: This research provides a theoretical contribution to our understanding of the ways in which national identity and dark tourism are linked. Taking a social construction perspective the empirical research design comprises 20 interviews with young American dark tourist site visitors, 11 of whom were re-interviewed. These repeat interviews take account of the reinterpretation of the tourists' experiences and ensure that the researchers' understanding of the first-round interviews was close enough to the interviewees' worldviews. We conceptualise the intricate and sometimes inconsistent stances that visitors take when explaining their dark tourism motivations and reflections and propose a new conceptual framework. 


\section{Introduction}

Dark tourism, the act of visiting sites associated with death, suffering, disaster and the overall macabre is not a new phenomenon (Seaton, 1996; Dann, 1998; Lennon \& Foley, 2000; Stone, 2006; Sharpley, 2009; Cohen, 2011). Historical gladiator games at the Roman Coliseum, the gathering of masses to watch public executions, visits to famous battle sites, and many other events connected to death and suffering are all representative of dark tourism (Seaton \& Lennon, 2004). These tourism experiences 'provide opportunities to explore oneself on an intrapersonal and, potentially, an interpersonal level' (Hede \& Thyne, 2010, p. 690). It should therefore be of no surprise that tourists increasingly assemble at one or more of the mass surplus dark tourism sites or that dark tourism has become a prolific topic for academic research in the last twenty years (for recent examples see: Biran, Poria, \& Oren, 2011; Cohen, 2011; Dunkley, Morgan, \& Westwood, 2011; Hyde \& Harman, 2011).

Yet, despite the recent increase in academic studies 'much of the literature remains supplyside focused whilst the motivation(s) for dark tourism has yet to be revealed and systematically interrogated' (Stone \& Sharpley, 2008, p. 576). Contemporary studies call for further empirical research; especially qualitative in-depth studies of dark tourism motivations and experiences (Dunkley et al., 2011; Podoshen, 2013). While there have also been several studies regarding the role of tourism in the process of national identity formation (Edensor, 1998, 2000; Chronis, Arnould, \& Hampton, 2012) such studies have focussed on heritage and tourism, not explicitly on dark tourist sites and behaviour (e.g. Joyce, Stevenson, \& Muldoon, 2013).

Important to note is that "the underlying theory for understanding dark tourism motivations as well as generating novel insights will be housed outside the boundaries of traditional tourism 
scholarship' (Podoshen, 2013, p. 269). As a consequence, the context for this study is broadly contained within the marketing domain. Interest in heritage from a marketing perspective can be located in the social and identity crisis experienced in contemporary society (Goulding, 1999) although a key point of differentiation between heritage tourism and dark tourism is that dark tourism is often associated with some type of atrocity (Sharpley \& Stone, 2009). Dark tourism sites afford an opportunity to 'write or rewrite the history of people's lives and deaths, or to provide particular (political) interpretations of past events' (Sharpley \& Stone, 2009, p. 8). Yet, how and in what ways these interpretations of dark tourist sites are then weaved into consumer narratives is under-researched.

In this paper we present an alternative way of thinking about dark tourism which explores its contribution to the collaborative creation of national identity. Our intention is to make a theoretical contribution to our understanding of the ways in which national identity and dark tourism are linked. This involves a consideration of the complex and sometimes contradictory positions that participants take when accounting for their dark tourism motivations and reflections. Tourism and consumer researchers have not attempted to understand tourists' various dark tourism visitor behaviours and reactions in terms of national identity construction (McCabe, 2000; Uriely, 2005). Similarly, although the role and influence of tourism in national identity has been considered, the national identity literature has not explicitly looked at dark tourism as part of this phenomenon (Nairn, 1997; Spillman, 1997; Pretes, 2003).

The research reported in this paper aims to develop our understanding of the behaviours and motivations of dark tourism and the social influences and responses in creating narratives and stories which co-create and reinforce national identity. This article has the following 
structure. Initially, we review key topics and research findings regarding tourism and national identity through an overview of the relevant literature. Secondly, we detail the methods employed to address our research objectives. Third, we present our findings and propose our conceptual framework, showing how dark tourism facilitates the co-construction of national identities in different contexts. Theoretical contributions and suggestions for future research provide a conclusion to the paper.

\section{National identity}

The phenomenon of national identity has provided a backdrop for debates about the nature of social bonds, individual affiliations and expressions of nationhood in a globalised word. National identity has a long history and its nature and significance has changed with historical, political and other circumstances (Nairn, 1997). Nationalism is not a sociologically 'natural' phenomenon like tribalism or regionalism, but the result of the deliberate efforts of the dominant political power to form a single homogenous, 'nation' from a multicultural, diverse population (Mosse, 1975; Hechter, 2000). Issues of national identity have taken on new significance in the context of globalisation, consumer culture, social media and the fragmentation of social structures (Spillman, 1997; Mitchell, 2001). According to Smith (1996, p. 121) it is 'myths of origins' frequently based on historical narratives that "form the groundwork of every nationalist mythology...telling us who we are, whence we came from and why we are unique'’.

Beyond historical, geographical and social bonds Anderson (1991) defines the nation itself as an 'imagined community', because the members of even the smallest nations will never know most of their fellow-members. None of this literature however has examined the link between the perceptions of the national brand per se and the citizens' experience of national identity. 
In addition to research on the branding of nations (Olins, 2001; Kulkarni \& Ganesh, 2002; Erdem, Swait, \& Valenzuela, 2006; Lee, Klobas, Tezinde, \& Murphy, 2010), there have also been several studies on the process of forming or reaffirming self and national identity via tourism (Edensor, 1998, 2000; Goulding, 1999; Peñaloza, 2000; Pretes, 2003; Macdonald, 2006; Chronis et al., 2012). Important findings include those of Palmer (2005) who examines how the national identity of 'Englishness' is constructed through tourists' experiences at three heritage sites: Battle Abbey, Hever Castle and Chartwell. She finds that these sites signify core aspects of Englishness, presenting the nation variously 'as a family, a group of relations with shared history, values and beliefs, and common characteristics' (2005, p. 7). This supports the view that tourism can facilitate a sense of belonging; although how these experiences are then conveyed in narratives co-creating national identity remains unexplored.

Similarly, Korean nationhood is explored by Park (2010) through visitors' experiences of Changdeok Palace, South Korea and shows how heritage tourism experience acts as a symbolic mechanism by which national belonging can be reconstructed and communicated. An important finding here is that heritage is not just a tangible manifestation of the past represented by artefacts and physical sites, but also encompasses intangible elements of symbolic meanings and spiritual embodiments. 'It may be asserted that heritage tourism is inextricably bound up with experiencing both material (tangible) and socio-psychological (intangible) remnants of the nation's past. Therefore, heritage can be better understood as both a material and socio-psychological testimony of identity' (Park, 2010, p. 133). Hede and Thyne (2010) report similar findings in their study of a literary museum.

The role of the intangible is further illustrated by one of the guides in the study of the Gettysburg site and its story by Chronis (2005, p. 397): '[Guide] As far as what brings people 
to Gettysburg, great deeds, something stays, bodies disappear [but] spirits linger, they consecrate the ground. . our country is formed here; by this battle; what happened here.'

This case further illustrates how professional staging and the guides' storytelling is not taken for granted by the visitors. While guides are 'conscious of the need to remind visitors of the scene in which they are in' (Hede \& Thyne, 2010, p. 697) their interaction can produce conflict which mainly arises from the perceived gap between tourists' familiarity with preestablished narrative and their new encounters and stories heard during their visit. For example, Chronis (2005) finds disagreements that result from regionally based identification, 'as when individuals from either northern or southern states become over-supportive of the Union or the Confederate side. Such contestation may be expressed through the employment of historical events in heated dialogues between tourists and guides' (Chronis, 2005, p. 393). He finally concludes that 'it is the poetic performance of the Gettysburg story that is highly responsible for the transformation of a bloody fratricide into a national narrative of unity; it is because of its co-constructed nature that Gettysburg is established as the birthplace of the American nation and its narrative becomes a myth of origins' (2005, p. 402).

While tourism clearly influences the creation of national identity, the relationship between national culture and so-called 'World Culture' is also instrumental to our understanding of what constitutes a national identity. In his essay, 'Universal Civilization and National Cultures', the philosopher Paul Ricoeur (1961) argues that national culture must also be a form of world culture, which depends on the capacity of the national culture to recreate a rooted tradition while appropriating foreign influences at the level of both culture and civilization through necessarily complex processes of cross-fertilization and reinterpretation. 'There is the paradox: how to become modern and to return to sources; how to revive an old, 
dormant civilization and take part in universal civilization.' (1961, p. 276). The past has a pervasive appeal and can be used to enhance concepts of the self or can reinforce bonds through a common experience. It is recognised that consumers seek experiences to confirm their social identities through a better understanding of their heritage (Goulding, 1999) and their nationhood.

One of the most important strands of consumer research attempts to understand 'the coconstitutive, co-productive ways in which consumers, working with market-generated materials, forge a coherent, if diversified and often fragmented sense of self' (Arnould \& Thompson, 2005, p. 13). By exploring the self in relation to national identity, this study will further contribute to an understanding of the concept of co-creation by exploring how the cocreative dynamic unfolds e.g. through a reinterpretation of the information provided in situ and/or because of conflict and provocation that triggers the co-creative process (Sharpley \& Stone, 2009). Kang, Scott, Lee, and Ballantyne (2012, p. 258) observe that in co-creating an experience consumers can adopt a 'hot interpretation' approach where a 'subjective interpretation of the past affords a significant dark tourism experience while offering insight and healing' to dark site visitors. Interpretation of the dark site can, however be affected by what is displayed, how other tourists experience the dark site visit as well as how the guide portrays the information to elicit empathy from or convey a message to the tourist (Chronis, 2005; Kang et al., 2012).

The strategy and organisational literature on co-creation has tended to be overlooked in the marketing discipline (notably Prahalad \& Ramaswamy, 2004) where the value co-creation concept has been developed predominantly from Vargo and Lusch's (2008) notion of Service-Dominant Logic (S-DL). This might explain why most of the marketing research has 
focused on services in the context of interfirm relationships and some B2C contexts. While several marketing authors have investigated the antecedents and constituents of value cocreation, others attempt to evaluate its impact and implications for business success. However, less is known or researched about the social roles enacted during the interaction process and within which interaction is embedded (Edvardsson, Tronvoll, \& Gruber, 2011; Grönroos, 2011; Lusch, Vargo, \& Tanniru, 2010). It is this aspect of the co-creation process where this study of tourism marketing and national identity may contribute to an understanding of how and in what ways experiences are (re)told as narratives to construct a sense of self. Importantly this progresses the notion of co-creation beyond S-DL.

Hogg and Michell (1996) observe that consumers have a number of self-images and it may be argued that national identity is similarly partial because the individual's identity as an American (or other nationality) does not make up the whole person; they also play other important roles as citizen, parent, professional, sister, neighbour etc. Indeed, that 'part' of the self which is an American is also necessarily in process because it changes according to life-stages, expenditure opportunities, outside influences, contexts, visits, interaction, travelling, events etc. The child for example has a very different understanding of their self as an American' compared to their later adult consumer 'self' (e.g., meanings, fantasies, desires and more mundanely issues regarding financial implications, responsibilities, etc.). Further, like the notion of the self, national identity may be compared to a bricolage, being constructed by mixing 'bits and pieces' from experiences, travels, commodities, fashions or appearance (Hebdige, 1979). It is these potential components in the construction of national identity that will be explored here in the context of dark tourism. 
While interest in death is a 'taste all share to some extent' (Seaton, 1996, p. 240), fascination for dark tourism may not be recognised as such and this too is important for our understanding of the motivation(s) of dark tourists. In other words, tourists who seek dark tourist sites may represent normal, rather than abnormal, behaviour (Seaton \& Lennon, 2004). If this is the case, visitors may not identify their motivations as particularly dark, but rather as a means for fitting in with the crowd, exploring historical interest (education), indulging personal fascination (entertainment), making sense of the past, enhancing one's status, and/or demonstrating national pride (Seaton, 1996; Goulding, 1999; Lennon \& Foley, 2000; Seaton \& Lennon, 2004; Stone, 2006; Biran et al., 2011; Cohen, 2011).

This study considers the role of national identity and examines the inter-relationships between the intricate and occasionally inconsistent stances that participants take when explaining their dark tourism motivations and reflections. Consequently the objectives of this research are threefold:

- To examine dark tourist motivations and behaviours in terms of national identity (co)creation

- To investigate the interplay between self and national identity in the context of dark tourism

- To develop a conceptual framework to explain the inter-relationships between motivations for visiting and narratives of experience of dark site tourists

\section{Research design}

A narrative analysis of visitors' stories around their experience of dark tourism sites is the principle methodology employed in this study. This qualitative approach aims to understand 
and explore emically the key influences and relationships, which are later expressed etically in terms of a diagrammatic conceptual framework. The narrative turn in social sciences (e.g. Boje, 1991; Christie \& Orton, 1988; Simmons, 2001; Bruner, 2002; Booker, 2005; Linde, 2009) suggests that human beings make sense of their lives by behaving as both storytellers and narrating themselves in their own stories. Boje defines a story as 'an oral or written performance involving two or more people interpreting past or anticipated experience' (Boje, 1991, p. 111) although arguably we also tell stories to ourselves even if we imagine the presence of another while we are doing so. Similarly, Shankar, Elliot, and Goulding (2001) emphasise the potential of a narrative perspective for theory and method in consumer research. Narratives are considered to be a fundamental way by which we structure and therefore make sense of our lives. Shankar et al. argue that the detailed study of narratives can contribute to our understanding of how consumers structure and make sense of their consumption experiences.

Hopkinson and Hogarth-Scott (2001) note there is widespread debate about the nature of story which is intertwined with a broader epistemological and ontological debate regarding the nature of reality and knowledge (Riessman, 1991). Hopkinson and Hogarth-Scott identify three 'key understandings' of the nature of story in marketing and more widely in social research. Firstly, story is a factual report of events which tells what happened with some contextualising information such as where it happened or who was involved. It provides a chronological listing of events without the complex linking of events through attribution of intention and effect or extended commentary. The emphasis is upon 'facts', thus excluding the teller's account of why the events took place, or why the events are worth reporting (Polanyi, 1982). Secondly, story is myth; i.e. a myth which describes the storyteller's already construed 
and fabulated version of events. Thirdly, there is story as narrative, where the authors define narrative as a means of coming to understand events and constructing the storyteller's reality.

In order to capture visitors' own accounts of their experiences of their dark tourism site visits emically and to explore the way in which these visits featured in future narratives, a two stage interview approach was employed. This empirical data-gathering phase of the research comprised a total of on 20 interviews with young American dark tourist site visitors (11 of whom were re-interviewed), as soon as reasonably practicable after dark tourist site visits; allowing the participants to contemplate their recent experiences and to avoid 'noise' effects associated with conducting an interview in situ. The second set of interviews was specifically designed to take into account the reinterpretation of the tourists' experiences and to ensure that the researchers' emically-derived understanding of the first-round interviews was close enough to the interviewees' worldviews.

The sampling approach was purposive with only respondents who had visited dark tourism sites selected so that they would be able to fully contemplate the motivations and account for their visits (Dann, 1981, p. 200). Furthermore, limiting the sample to prior visitors decreased the variation of responses and presented a more cohesive set of narrative accounts than a comparative sample of visitors and non-visitors. The respondents were between the ages of 18-26 because of the significance of the young tourist to the future prospects of the tourism industry (Carr, 1999) as well as the paucity of research on the youth tourism market (Reisinger \& Mavondo, 2002). Using a snowballing technique which started with the social network of one of the authors, early participants provide introductions to potential interviewees to ensure less homogeneity. Students as well as part-time and full-time 
employed respondents were encouraged to take part in the research to ensure diversity of experience within the sample frame.

Dark tourism sites relevant to Americans were chosen for exploration and the respondents were also US citizens to allow a focus on US visitors. Visiting dark sites could have relevance to the national identity of other visitors. However other nationalities would perhaps know less (or care less) about events that took place at these dark tourism sites and may view the sites from other national perspectives. Analysis of such varied responses would potentially be overly complex. However, further research could explore the extent to which dark tourism and national identity is relevant to tourists or tourism per se within a country.

This study is based on 13 different dark tourism sites as detailed by the respondents. Sites were categorized in accordance with Stone's (2006) seven classifications of dark suppliers along the dark tourism spectrum (darkest to lightest) and were identified as purposeful or accidental (see Table 1). The majority of sites visited were at the darker end of the spectrum and this is likely to be attributable to dark tourism being especially attractive for young visitors who are known to seek fear and thrill to increase their levels of pleasure and enjoyment during their tourism experiences (Mura, 2010). Goulding (1999, p. 658) suggests that tourists are drawn to 'mediums that reflect their own age culture'. The dark sites visited by the respondents typically reflect this assertion. All site visits were day visits. Interviews lasted on average 45-60 minutes. Data collection was sufficient to ensure saturation (Guest, Bruce, \& Johnson, 2006). 
Table 1: Sample Demographics

\begin{tabular}{|c|c|c|c|c|c|c|c|c|}
\hline Pseudonym & $\begin{array}{ll}\text { US-based dark site } & \text { Dark } \\
\text { visit/s } & \text { (S }\end{array}$ & $\begin{array}{l}\text { k site category } \\
\text { Stone, 2006) }\end{array}$ & Age* & Education & Gender & Occupation & $\begin{array}{l}\text { Marital } \\
\text { status }\end{array}$ & $\begin{array}{l}\text { Accidental/ } \\
\text { purposeful site }\end{array}$ \\
\hline$\overline{\text { Dane }}$ & $\begin{array}{l}\text { The United States Holocaust } \\
\text { Memorial Museum, DC }\end{array}$ & Darker & $23 / 24$ & College & $\bar{M}$ & HR assistant & Single & Purposeful \\
\hline \multirow[t]{3}{*}{ Bruce } & $\begin{array}{l}* * * \text { The United States, Holocaust } \\
\text { Memorial Museum, DC }\end{array}$ & Darker & $26 / 27$ & Masters & M & Teacher & Married & Purposeful \\
\hline & $\begin{array}{l}\text { The Sixth Floor Museum } \\
\text { at Dealey Plaza, Dallas }{ }^{1}\end{array}$ & Darker & & & & & & Accidental \\
\hline & $\begin{array}{l}\text { Maritime Museum of the Atlantic, } \\
\text { Halifax, Nova Scotia }\end{array}$ & Darker & & & & & & Purposeful \\
\hline Charlie & $\begin{array}{l}\text { Pearl Harbor, US Navy Base, } \\
\text { Oahu, Hawaii }\end{array}$ & Darker & $25 / 26$ & College & M & Special effects artist & Single & Accidental \\
\hline Max & $\begin{array}{l}\text { One World Trade Center, } \\
\text { Lower Manhattan, New York City }\end{array}$ & Darker & $21 / 22$ & College & $\mathrm{M}$ & Student/Server & Single & Accidental \\
\hline \multirow[t]{3}{*}{ Peter } & $\begin{array}{l}\text { The United States Holocaust } \\
\text { Memorial Museum, DC }\end{array}$ & Darker & $18 / 19$ & High school & M & Student/Cook & Single & Purposeful \\
\hline & $\begin{array}{l}\text { Vietnam Veterans Memorial, } \\
\text { Washington, DC }\end{array}$ & Dark/Light & & & & & & Accidental \\
\hline & $\begin{array}{l}* * * \text { Arlington National Cemetery, } \\
\text { Washington, DC }\end{array}$ & Dark/Light & & & & & & Accidental \\
\hline
\end{tabular}




\begin{tabular}{|c|c|c|c|c|c|c|c|c|}
\hline \multirow[t]{2}{*}{ Karl } & $\begin{array}{l}\text { One World Trade Center, } \\
\text { Lower Manhattan, New York City }{ }^{4}\end{array}$ & Darker & $24 / 25$ & College & M & Music teacher & Single & Accidental \\
\hline & $\begin{array}{l}\text { Flight } 93 \text { Memorial, } \\
\text { Pennsylvania }\end{array}$ & Darker & & & & & & Accidental \\
\hline Tim & $\begin{array}{l}\text { The United States, Holocaust } \\
\text { Memorial Museum, DC }\end{array}$ & Darker & $23 / 25$ & Diploma & $\mathrm{M}$ & Electrician & Single & Purposeful \\
\hline Brynn & $\begin{array}{l}* * * \text { Flight } 93 \text { Memorial, } \\
\text { Pennsylvania }\end{array}$ & Darker & & & & & & Accidental \\
\hline Lynn & Salem, Massachusetts ${ }^{5}$ & Dark/Light & $26 / 28$ & Masters & $\mathrm{F}$ & Instructor & Single & Accidental \\
\hline \multirow[t]{2}{*}{ Melrose } & $\begin{array}{l}\text { Pearl Harbor, US Navy Base, } \\
\text { Oahu, Hawaii }\end{array}$ & Darker & $22 / 23$ & College & $\mathrm{F}$ & Customer associate & Single & Accidental \\
\hline & $\begin{array}{l}\text { One World Trade Center, } \\
\text { Lower Manhattan, New York City }\end{array}$ & Darker & & & & & & Accidental \\
\hline Maura & $\begin{array}{l}\text { One World Trade Center, } \\
\text { Lower Manhattan, New York City }^{7}\end{array}$ & Darker & $21 / 23$ & College & $\mathrm{F}$ & Student/Waitress & Single & Accidental \\
\hline Tessa** & $\begin{array}{l}\text { Pearl Harbor, US Navy Base, } \\
\text { Oahu, Hawaii }\end{array}$ & Darker & 19 & College & $\mathrm{F}$ & Student/Sales & Single & Accidental \\
\hline Karlie** & $\begin{array}{l}\text { The Sixth Floor Museum, } \\
\text { at Dealey Plaza, Dallas }\end{array}$ & Darker & 26 & College & $\mathrm{F}$ & Sales & Single & Accidental \\
\hline
\end{tabular}




\begin{tabular}{|c|c|c|c|c|c|c|c|c|}
\hline Joanne** & $\begin{array}{l}\text { The Sixth Floor Museum, } \\
\text { at Dealey Plaza, Dallas }\end{array}$ & Darker & 26 & Masters & $\mathrm{F}$ & Substitute teacher & Single & Accidental \\
\hline Alexis** & $\begin{array}{l}\text { The United States Holocaust } \\
\text { Memorial Museum, DC }\end{array}$ & Darker & 20 & Diploma & $\mathrm{F}$ & Hair stylist & Single & Purposeful \\
\hline Walter** & $\begin{array}{l}\text { Battle of Lynchburg site, } \\
\text { Virginia }\end{array}$ & Dark & 25 & College & M & Student & Single & Accidental \\
\hline Paul** & $\begin{array}{l}\text { Vietnam Veterans Memorial, } \\
\text { Washington, DC }\end{array}$ & Dark/Light & 24 & Diploma & M & Airplane mechanic & Single & Accidental \\
\hline Michael** $^{* *}$ & $\begin{array}{l}\text { Jamestown Settlement, } \\
\text { Living History Museum, Virginia }\end{array}$ & Darker & 25 & Diploma & M & Technician & Single & Accidental \\
\hline Joanne** & $\begin{array}{l}\text { One World Trade Center, } \\
\text { Lower Manhattan, New York City }{ }^{10}\end{array}$ & Darker & 21 & College & $\mathrm{M}$ & Student & Single & Accidental \\
\hline
\end{tabular}

*Age at first and second interview

**Respondents interviewed only once - all others re-interviewed a second time approximately 12 months after the first interview

***Most recently visited dark tourism site explored in interview (where relevant)

\footnotetext{
${ }^{9}$ The Texas School Book Depository

${ }^{10}$ Freedom Tower, one site of the 9/11 terrorist attacks on the United States
} 
Following McCracken (1988), 'grand tour' questions were used to encourage informants to discuss their own experiences in their own way. Planned prompts as suggested by McCracken were used to facilitate the narrative, for example: category specific prompts such as, 'what was most striking about the visit?' and 'what was most surprising about your experience?' aided the discussion. Employing techniques suggested by McCabe (2000) the organisation, wording and flow of questions became more or less open-ended and were adapted by the researcher as conversations progressed to allow for a mixture of responses and in order to permit respondents to give their accounts in their own words. Topics included reflections on: reasons for visiting dark tourism sites, short/longer-term responses and reactions to dark tourism site visits, activities undertaken while at dark tourism sites as well as contextualising dark tourism site visits by exploring 'typical' holiday-making.

The first set of interviews was analysed and the respondents' explanations of their motivations for visiting dark tourism sites were categorised and mapped. Approximately 12 months after the initial research interviews participants were approached and invited for a second interview; eleven of whom agreed. The second set of interviews was specifically designed to capture the respondents' relative interpretations as building on those expressed in their original interviews. This required firstly establishing from respondents that their full accounts of their tourist behaviour and experience had been accurately captured by the researchers' accounts of their initial narratives. Secondly it necessitated subsequent second interviews to explore additions, corrections, misinterpretations or reconsiderations of the respondents' original accounts.

Our analysis of the two sets of interview accounts employed analytic induction (Bryman \& Burgess, 1994) and the constant comparative method in order to explore the themes which 
were revealed in the respondents' narratives. Each interview was examined to gain a holistic understanding of the respondent, making notes of themes as they transpired (Thompson \& Hirschman, 1995). All the themes were reviewed through iterations of comparison and rereading. The interpretations developed were as a consequence of the relationship between emerging insights and prior assumptions (Spiggle, 1994).

\section{Data analysis}

The findings are categorised employing an emic analytical framework using the narratives of the respondents. These insights are then integrated to produce an etic model where the outside view affords an opportunity to consider patterns of behaviours (Morris, Leung, Ames and Lickel, 1999) across dark tourism sites. The narratives illustrate how and in what ways respondents experience their dark tourism site visits and reflect affirming and negative as well as contrary accounts of their encounters.

\section{Stories of individual and social experiences of dark tourism site visits}

Respondents reflected through their accounts of their dark site visits that their experiences were individually role reinforcing and educational as well as affording an opportunity to bear witness to a tragic event/s. Dark site visits also engendered collective homage in addition to feelings of belonging and pride. There was also incidents of disassociating with other national groups to emphasise what constitutes 'being a good citizen'. These findings build on and further develop suggestions from previous studies (Seaton, 1996; Lennon \& Foley, 2000; Seaton \& Lennon, 2004; Stone, 2006; Biran et al., 2011; Cohen, 2011) that indicate motivations for dark tourism site visits include exploring historical interest, complying with social norms and demonstrating national pride. 
(Re)Affirming Individual Roles

Interestingly a number of respondents reflected that their dark site visit was not necessarily as a result of fascination with the macabre (Stone, 2006); rather the experience of the visit offered an opportunity to enhance an individual self-identity or 'role' which had been adopted or ascribed. In the following excerpt, Lynn who identifies as a 'Goth' narrates her visit to Salem, the location of the Salem Witch Trials, 1692. Her reason for visiting Salem was because '[Salem] is so full of history and I really am personally interested in the history of witch hunts'; in part to enhance her role as a Goth as well as assuage her interest: 'And there are so many literary things tied up with [Salem] as well like Nathaniel Hawthorne and the Crucible and things like that. So I wanted to go and see where it had happened.'

Similarly, Karl's visit to the Flight 93 Memorial, Pennsylvania, was to support and enhance his role as a teacher. He observes that as his students had already attended this dark tourism site he was obliged to have the same experience to be able to 'share' the visit. Also the notion of dark tourism sites having educational properties is supported here (Seaton \& Lennon, 2004):

I visited [Flight 93 Memorial] because when they opened up that exhibit this past year a lot of my students said it was really cool so I went down and visited that. I didn't know it had opened [the exhibition] but my students went down and they said it was awesome. After hearing it from my students they said that the president was there and a lot of my students got to see the president and his wife. I thought that was really cool and really educational for them - me being the cheesy teacher inside of me I was really excited that they were kind of expanding their historical knowledge. So I thought I'd have to go to. 
Bearing witness to a tragic event is also revealed through the respondents' narrative. For example, Brynn notes here that her visit to the One World Trade Center $^{11}$ is partly to remember those who lost their lives and partly to observe the dark tourist site where the event took place. She illustrates what Goulding (1999) describes as 'a strong feeling of "loss", not of others but of an ideal' (p. 661). Importantly Brynn recalls 'signing a book' to make sure there was an individual and personal record of her trip:

I think people go to these places to remember those people who died or lived or survived or became heroes - I think that's why people really go to these places. I wanted to go because I was alive during that time [9/11] and I knew all about that situation and I just felt like - you know like people who go and visit Pearl Harbor who were alive during that time - it's something they want to see even though it was so tragic - they just want to see it. I did sign a book to say I was there.

Respondents also suggested that visiting sites, museums or exhibitions associated with death and suffering afforded an opportunity to reaffirm their own values. Although disassociating with the behaviours recorded and illustrated at dark tourism sites, Tim makes repeat visits to the Holocaust Memorial Museum, DC. This may reflect the observation of Hede and Thyne (2010) who suggest that experiences pave the way for future behaviours. While describing his day trips, an educational element is evident in his visit e.g. recalling details of the Holocaust. However Tim also notes in a dissociative manner that he finds the museum 'disgusting':

\footnotetext{
${ }^{11}$ While we refer to One World Trade Center in the paper for consistency purposes, in our data analysis we report terminology in the respondents' own words and as a consequence different terms may be used to refer to the site of the $9 / 11$ terrorist attacks
} 
It's something that happened in history that you need to pay homage, well not homage exactly but you need to, I feel I need to keep it [the distasteful feeling/s] fresh. You forget details, sometimes you just need a refresher and it's a very interesting museum. Just things you wouldn't even think were possible are there obviously. I find it interesting, I find it disgusting but it draws you in.

While respondents generally expressed their encounters with dark sites as both an individual and collective experience, each interviewee placed an emphasis on the event as either individual or social. There appeared to be no patterns between individual and social encounters in relation to particular dark tourism sites e.g. more recent dark tourism sites relative to those that were more historical or amongst respondents (male or female). However, social experiences for dark tourism site visits were characterised by reference to an ‘imagined community' (Anderson, 1991) and/or what it was to be an American citizen and the implications thereof. Though Goulding (1999) notes, there is the possibility that heritage sites 'use the past to maintain values that never existed' (p. 649).

\section{Longing and belonging}

Respondents when reflecting on their experiences of dark tourism site visits, often began sentences with 'as an American...' reinforcing that certain responsibilities and behaviours were thought to be expected of a US citizen. Karl here exemplifies the notion of paying collective homage to those in the imagined community who are part of American culture:

[The attack on the World Trade Centers] plays such an important role in history. Um, because it's like an important site in history and like, it's one of those things I feel like 
everyone needs to see. I mean, I don't want to play the card, like, "If you're an American ...”, but I mean, really that's a big part of our culture.

Melrose, who lives in New York, furthers this notion of engaging others in paying homage by indicating that her repeat visits to the Freedom Tower are predicated on taking her visitors there to share the experience: 'Every time I've gone to the World Trade Centre site it's because someone has come to visit and I've taken them up. I mean we're all connected because we're all American.'

This connection or 'belonging' (see Palmer, 2005) is also evident in the narratives of other respondents in the sample. The values associated with what it is to be an American citizen is epitomised here by Maura who co-constructs American national identity as one which is typified by both resilience and pride:

I guess the Freedom Tower is about national pride. Especially now - even though it's still Ground Zero and it still has all that stuff there [associated negative memories], the sense of pride you have being there and looking at the Freedom Tower it's just like you are really proud that we [the Americans] came back from something like that. It's not just a sad feeling anymore. That's why we go.

This pride can also be used to enhance citizenship. For example, Tim describes his visit to Arlington National Cemetery as inspiring all Americans to be similarly honoured:

Arlington Cemetery is one of the most respected cemeteries in the world. It's an honour to be buried there - I would say. Everyone should go to pay their respects. 
Presidents are buried there - everyone who has been a US world figure is buried there.

Interestingly Maura notes that although deciding to visit a dark tourism site can elicit complex or contrary emotions, on reflection it engenders notions of citizenship and resilience as well as what it is to be an American:

It's like coming back [from the attacks on the World Trade Centers], gaining momentum, coming back for America. Like I am sure that going through the whole memorial is still really hard for people but the fact that that tower is there it's really like a big thing of how we have come back from.

These respondents illustrate that their experiences of visiting dark tourism sites (and sometimes repeat visits) are underpinned with national pride, the responsibilities associated with their citizenship and belonging to an 'imagined community' (Anderson, 1991). Fascination for the macabre (Stone, 2006) is limited here. In the section that follows, the respondents' experiences of dark tourism site visits are examined through both tangible and intangible elements (Park, 2010). However, expectations of dark tourism site visits are not always met and the portrayal of American national identity through tangible elements does not always reflect the experience of the respondents.

\section{Symbols and symbolism of dark tourist sites}

Respondents though their narratives readily identified tangible elements or symbols at the dark tourism sites they visited as being illustrative of American national identity (e.g. flags, newspapers heralding war success, wrist bands). Intangible elements included the role of the 
tour guide in shaping an understanding of the physical site as well as the spiritual embodiment associated with the individual locations supporting the work of Chronis (2005). The accuracy of historical detail at the dark tourism sites enhanced the respondents' appreciation of the sacrifice made by those honoured at dark tourism sites while inaccurate details reduced the impact of articles.

Some tangible aspects of the experience could be taken from the site dark sites and were described as being symbols of national unity. John notes that "everyone made a donation at the 9/11 memorial" and that the wrist band he received in return he "wore all day - even down to Battery Park" which was the next stop on his itinerary. He noted he could identify others who had also been to the One World Trade Center during his trip through the wearing of the wrist bands.

Importantly the portrayal of tangible aspects of American national identity was not always passively accepted by the respondents. Charlie illustrates here that dark tourism site visitors are active as opposed to passive in appropriating and co-creating a national identity. Cocreation as expressed in Charlie's story is triggered by provocation and conflict (Sharpley \& Stone, 2009). The process of national identity formation through dark tourism visits is both complex and multifaceted. For example, the use of the word 'bragging' here suggests that Charlie perceives the portrayal of American national identity to be arrogant and he is sceptical here of the way in which such (individual) sacrifice has been rewritten to promote the (collective) nation. His intonation reflects that the depiction of national identity at Pearl Harbor does not necessarily reflect his view of what it is to be an American: 
When you walked into the site [Pearl Harbor], it was more like 'We're America, we're great!' - there are American flags everywhere - almost like a bragging type of thing. Like 'We beat the Japanese', 'Here's the newspaper, we won the war!' 'America's great!' Here are the things they used to use in the war, here's an America flag - it was more about honour and respect America than the memory of it but I guess it was a mixture of it. Part memorial but mostly 'America is great - we won'.

Similarly Bruce questions the tangible aspects of his dark tourist experience of the Holocaust Memorial Museum in Washington. While his interest in the site was piqued by its historical context and the opportunity to enhance his self-identity as a teacher, the use of the contemporary children's toys in the display detracts from the visit. Although not directly related to national identity, this narrative excerpt illustrates the significance of tangible elements of dark tourism site visits to the (potential) co-construction of (national) identity. Further it can be seen here that the inauthentic has become as much a part of the experience as the authentic (Hede \& Thyne, 2010, p. 687). However, if the tangible elements lack credibility, there could be a halo effect where other aspects of the dark tourism site could be questioned. Importantly authenticity is a key component for eliciting tourist empathy (Kang et al., 2012):

Probably the thing I hated about it [the Holocaust Memorial Museum] because I'm a teacher is that I went through the kids section and in accommodating and adapting it to the kids' level they modified it all. And I went through and there were things I was pointing out and going 'that's not historically accurate', 'that's not relevant' - just because it's for kids. I mean I understand that, but there is a difference between 
completely changing it and then adapting it to where kids can understand it. They need to learn history. They shouldn't be changing it.

Narratives also illustrated that the intangible can be made tangible by the tour guide as observed by Chronis (2005). Here Karl recounts a repeat visit to the One World Trade Center and notes that the guide is not only able to develop an understanding of this dark tourism site but that Karl is subsequently able to enhance his own role as a teacher through this experience:

I think it was more emotional [a repeat visit to the One World Trade Center] because taking a group of high school kids who have never left the country or never left the farm, because those kids were like third grade when [the attacks on the World Trade Centers] happened. For them, and to see how emotional they became. I mean these kids were sobbing — it made me feel emotional. Our tour guide did a really good job of putting it in perspective. Because we were in a building and they showed us pictures of what the building looked like right after the towers collapsed. It was so surreal for the kids that it just really opened their eyes to that. To me, it was like the cheesy teacher in me - it was cool for me to see them growing.

Michael also notes his visit to the Jamestown Settlement, Virginia, is guided by the 'chief archaeologist on site' that 'made the site come alive through telling stories of just how bad winters were for the settlers'. Most striking for Michael about the visit was that a piece of $17^{\text {th }}$ century pottery was found while he was at the site which offered tangible and spontaneous confirmation of the historical nature of the experience. 
In Brynn's narrative, she explains that making the transition from intangible to tangible is not always a straightforward process. Indeed respondents are often observed holding contradictory positions about their dark tourism site visits; supporting the assertions of Hogg and Michell (1996) that individuals hold a number of self-images. As with Bruce, Brynn recognises that the dark tourism site visit produces conflicting emotions (i.e. pleasure, excitement and sadness) and contrary positions and perspectives can be evident in the same experience:

At first [when visiting the Flight 93 Memorial] I don't want to say I was excited that's not the right word - I was expecting to see where people died but I was interested to see it but once I was there I almost felt uncomfortable that I was trespassing on these people's lives. I had to leave.

Similarly Alexis walked through the Holocaust Memorial Museum 'probably faster than was polite' to assuage the 'horrifying' experience. However, the site visit made her more appreciative of being a US citizen as 'America has systems and securities in place to ensure this would never happen here'.

These conflicting or contrary positions would suggest the notion of fragmented self (Arnould \& Thompson, 2005) in the context of dark tourism and that the co-creation of national identity through dark tourism site visits is not necessarily a fixed but a fluid concept. Cocreation can be influenced by the tangible e.g. the physical site (Park, 2010) but also by the way in which these sites portray national identity. The credibility of the articles or information at the dark tourism site and the extent to which respondents actively appropriate their national identity in relation to their own roles as well as in a social collective context 
also contributes to the co-creation of a self and national identity. The following section considers the way in which the respondents use their narratives to co-create a national identity in the aftermath of their dark tourism site visits and how these narratives can help cocreate a self-identity as well as a collective national identity.

\section{Co-creation of self and national identity}

The co-creation of the self through dark tourism experiences and associated narratives relate to national identity but portrayals of the nation and what it represents are not submissively acknowledged. Charlie here explores his individual co-creation of national identity following a dark tourism visit to Pearl Harbor. The idea that national identity is not a 'fixed' but 'fluid' concept is further developed here as Charlie suggests his perception of America differs from other US citizens. In this narrative excerpt, national identity can be compared to a bricolage (Hebdige, 1979): 'I'm not political. I love America but I'm not going to be like Jay Leno [TV presenter] and wear a little American flag every day. That's pretty much what they sold [at Pearl Harbor] - and posters and stuff.'

Charlie's dark tourism experience has facilitated the construction of his own national identity by mixing 'bits and pieces' of what he considers is representative of his self-identity. Similarly, Karl's narrative following his dark tourism visit to the One World Trade Center affords the opportunity to enhance the credibility of his own 'story' as he can demonstrate he was experience-near the disaster by engaging with the American owner of the delicatessen as well as being able to illustrate how the owner 'recovered' from the tragic event:

I remember when we were going to leave [One World Trade Center], we kind of walked down this other side street and we walked into this small delicatessen for like 
a sandwich or something, and we asked the owner, like, 'were you guys here during 9/11?' And he's like, 'oh yeah'. And he said, 'it took me about a year to get this place clean again, and renovated and back up and working.' So ... it was just really cool to hear, well, I don't want to say it was cool, but it was interesting to hear his story because he really went through it. Like, he was a block away.

This also supports the recent findings of Podoshen (2013) as this dark tourist can be seen to seek out experiences for simulation and affect as well as to deepen an understanding and commemorate the tragic event.

A social collective approach to the co-creation of national identity (Yngfalk, 2013) is also revealed through the stories of the respondents. The following narratives illustrate that cocreation of national identity can be both inclusionary and exclusionary. In this way, (perceptions of) national identity can be enhanced with 'out-groups' identified and rejected as identified by Bruce:

There was a girl there [at the Holocaust Memorial Museum]. She was wandering around with a sweatshirt that had 'Germany' written on it. Normally you would just think 'oh she must be German' but you wonder if she really thought about what she wearing that day. You're thinking is she a big fan of this stuff, is she - that was really awkward.

This illustrates how other tourists can affect the dark site experience (Kang et al., 2012) as well as providing evidence of nationalism (Smith, 1996) and patriotism. This also supports the work of Nigbur and Cinnirella (2007) who report that their respondents had a high 
identification with greater in-group bias and an overall more positive autostereotype when examining the effects of national identification in Germany and Britain. It would appear here that not only is felt state of social or national identity stronger when compared to other nations; national identity is fluid and can be considered as a continuum. That is, there are varying degrees of felt national identity that are situation and experience specific and that national identity, like self-identity, evolves over time.

Melrose recalls a similar experience at Pearl Harbor where national identity is set in the context of world culture. This also emphasises that a national identity is shaped by appropriating foreign influences (Ricoeur, 1961):

When I was at the Pearl Harbor memorial the Americans were furious because there are a lot of Japanese people - I mean it's so close - that's why they come. And they [the Japanese] have guided tours of the Pearl Harbor museum in Japanese. And it's like, I don't know, do we have tours over there of where Americans bombed them?

Co-creation of national identity for this youth sample is both individual and collective. It is not fixed but (continually) interpreted and appropriated by accepting, rejecting and reinforcing perceptions of national identity.

These perceptions of national identity are illustrated here as relevant to dark tourism experiences. Co-creation of national identity and can be viewed as bricolage and can be both changeable and context specific. These narratives, which build on the notion of self and collective identity through dark tourism experiences, have supported the development of an 
etic conceptual framework model (Morris et al., 1999) that helps to explain youth motivations for dark tourist site visits and the co-creation of national identity (see Figure 1). 


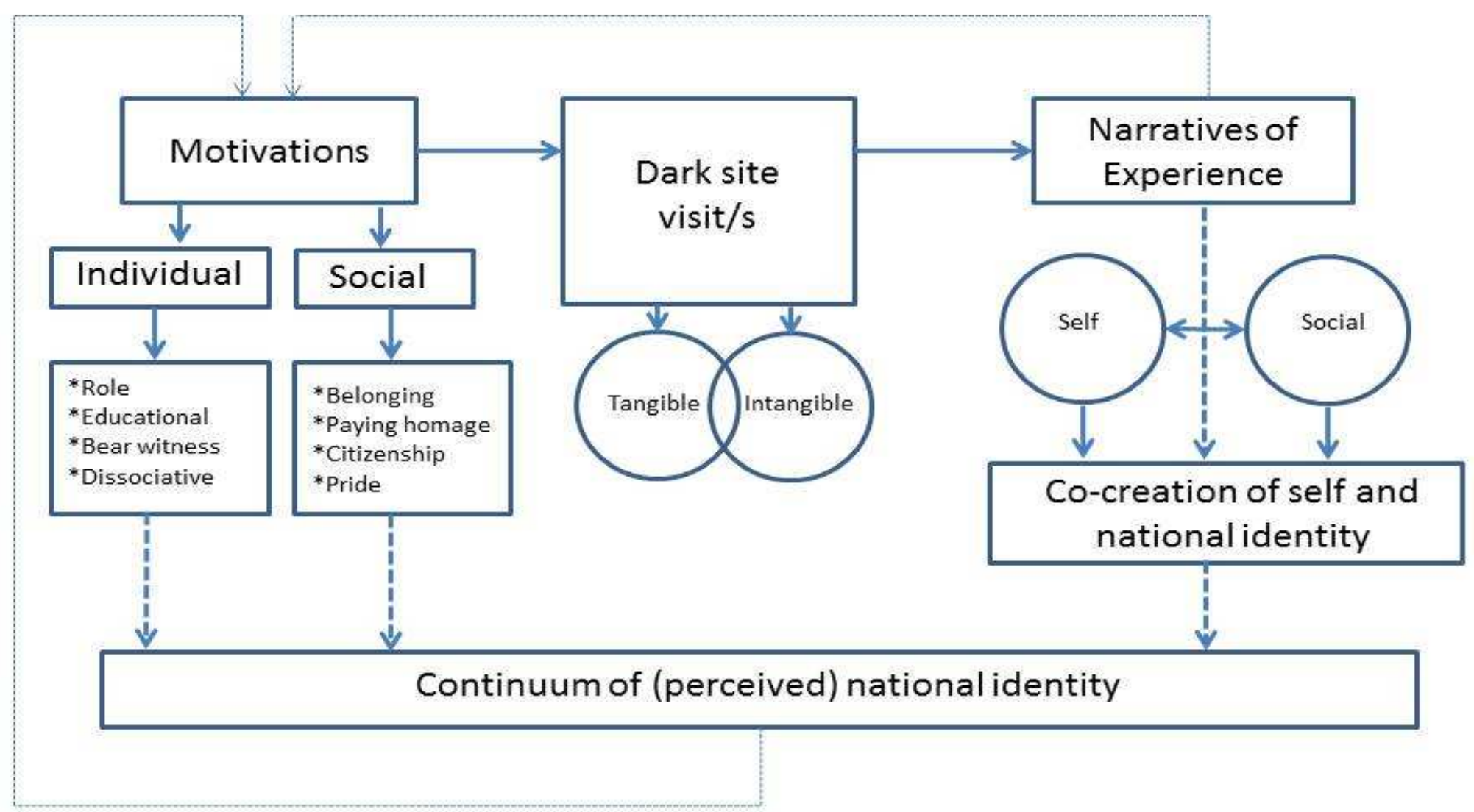

Figure 1: Youth motivations for dark tourist site visits and the co-creation of national identity. 
This etic framework, generated through emic insights, is composed of three constituent parts namely: motivation/s for dark tourism site visit/s, the experience of the visit/s and evolving narratives shaped as a consequence of the dark tourism site experience/s. Importantly while respondents report both individual and social motivations for their dark tourism site visit (as well as repeat visits), each visit is appropriated by the respondent to project a self and/or national identity. Felt or perceived state of national identity is depicted here as a continuum as data revealed respondents variously interpreted how America as a nation is portrayed and perceived and the meaning this had for their own and collective identity. This was context specific. Respondents with an increased number of dark tourist site visits did not always recount an enhanced felt state of national identity. However, in-group bias was heightened when out-group members were visible e.g. tourists from other nations. That is, the American respondents in this sample were more likely to report an enhanced sense of national identity when positioning themselves in relation to the Japanese or German tourists in the context of their dark site visit.

The inter-relationships between the constituent parts were evident in the association between the self and the social identity and the tangible and intangible aspects of the dark tourism experience. For example, data showed that respondents made repeat visits to dark tourism sites to engage with others but also to promote a collective sense of belonging to their own nation. Respondents drew on different elements of their dark tourist site visit(s) to illustrate their co-creation of inter-related roles that were appropriated or ascribed. Tangible elements of the dark site visit, including artefacts, were accepted or rejected to facilitate co-creation of a self and/or national identity. Similarly intangible elements, including the role of the guide, promoted a collective co-creation of the dark tourism experience through both narratives of the self and national identity. 


\section{Discussion}

This research considers and reflects upon the role of dark tourism motivations, experiences and behaviour in the co-construction of national identity amongst an American youth sample. Dark tourist behaviours and motivations have been captured from visitors' own narrative accounts with particular reference to co-creating a national identity. These accounts illustrate the way in which these respondents use their dark tourism experiences and narratives to cocreate a national identity at both a social and individual level. This builds on and contributes to the growing body of literature in the marketing discipline which examines consumers' interactive and co-creative experiences (e.g. Brodie, Hollebeek, Jurić, \& Ilić, 2011). Similarly dark tourism scholarship will benefit from this study which provides new insight that moves beyond specific heritage-related factors (Podoshen, 2013).

The role of consumers in negotiating and contesting various market-based 'meanings' is more widely recognised (Arnould \& Thompson, 2005; Schembri, 2009; Schau, Muñiz, \& Arnould, 2009) and the active role of dark site visitors in their co-creation of meanings appears to fit well with this conceptualisation. In marketing, Vargo and Lusch (2008) conceptualise service as a value creation process and value as an interactive construction between 'actors' previously labelled as providers and consumers - who are now called 'resource integrators' (Akaka \& Chandler, 2011). Similarly visitors and tour guides as well as other relevant actors may similarly be regarded as resource integrators in the value co-creation process in this tourist marketing case. This also suggests that 'co-creation' is intrinsic in the interpretative, collaborative and social nature of humankind and not the exclusive tool of S-DL.

Instead of simply belonging to the tourism experience, these findings illustrate that the respondents 'belong to the narrative' (Cary, 2004). This study also explains the contradictory 
positions participants take when accounting for their dark tourism motivations and behaviour. Interestingly, and contrary to Stone's (2006) dark tourism spectrum, these dark tourists demonstrate less fascination for the macabre and instead use their experiences to narrate stories of nationhood.

Respondents as well as tour guides were able to transform tragedy into national unity. Outgroup-members (non-US tourists) were identified and rejected where national identity was perceived as being challenged, whilst the US values of the 'imagined community' (Anderson, 1991) were positively reinforced. Data, however, suggested a continuum of felt state of national identity with some respondents being more patriotic or nationalistic than others. That is, rather than passively 'experiencing' national identity through tourism (Palmer, 2005), these findings suggest that there are continually evolving degrees of (felt) national identity which vary for the self as well as the social collective.

Our findings support the work of those who recognise that dark tourists are not necessarily fascinated with the macabre but will visit these specific locales for educational purposes, entertainment and to enhance national pride (e.g., Seaton \& Lennon, 2004; Biran et al., 2011; Cohen, 2011). However, this research adds to an understanding of dark tourism behaviour by explicitly considering the role of national identity co-construction through these experiences. Furthermore, this study questions the assumption that the 'youth' may be blasé or desensitised when reflecting on their dark tourism site experiences (see Dann, 2005) or that thrill seeking is a key component of youth tourism experiences (Mura, 2010). There is clear evidence here of an understanding of sacrifice, loss and tragedy. Respect, pride, and humility are also apparent in these co-national construction processes. Given the paucity of research on youth tourism (Reisenger \& Mavondo, 2002) understanding the significance of dark 
tourism in co-creating a self and national identity contributes to knowledge in this area. These findings may also contribute to an understanding of loyalty (repeat visits) in the consumer travel industry (Richard \& Zhang, 2012).

The conceptual framework (Figure 1) could be used in further research to explore youth narratives in relation to experiences that are co-created and facilitate a greater understanding of the way in which felt state of national identity can encourage consumption behaviours and/or changes in motivation and attitudes. It may also help explain word-of-mouth communication in the travel industry (Liang, Ekinci, Occhiocupo, \& Whyatt, 2013), where Hankinson (2009) finds that 'to be successful, destination brands must go beyond the communication of an image and make the brand promise a reality' (p. 111). One potential managerial implication of these findings is that tourist site managers and marketers could better support tourists post-visit consumption activities by constructing visitor experiences which afford consumers opportunities to recreate their experiences in future narratives and thereby influence their notions of national identity.

There are several suggestions for methodological developments in future research studies on this topic. A more limited number of dark tourism sites visited by respondents could be selected in order to better comprehend the influence of other visitors on their perception and interpretation of the place and their experience. The type of dark tourism site could be varied too. Behaviours and reactions to dark tourism site visits might be expected to be different for an older or much younger group of respondents. Also, since our study only considers US citizens, an international study incorporating European and Asian dark tourism sites would add a broader understanding of national identity co-creation in a wider cultural context. 
There are three additional suggestions for further research. Firstly although they were asked about their typical holiday behaviour, the respondents here were all dark tourists. It would be interesting to compare these findings with the motivations and behaviours of those who did not visit dark tourism sites but who also use their tourism experiences to co-construct national identity. Secondly, the dark tourism sites in this study were a mixture of both purpose-built and accidental/unintentional dark tourism sites. Purpose-built sites 'interpret or recreate events or acts associated with death and the macabre', whereas non-purposeful (accidental) sites have become tourist attractions simply by their association with death and disaster (Stone, 2006, p. 148). As Stone notes, not only does the site's formation affect the type of visitors it attracts but the amount of tourism infrastructure. Further research could focus on one or other type to examine any differences in motivations and perceptions between the two and any subsequent influence on national identity co-construction.

Finally the effects of branding a nation in the context of dark tourism development could build on the work of Skinner (2008) as he observes, 'places have been urged to consider the images they ... present to the world and how these images are perceived and consumed by various target markets' (p.921). The findings illustrate here that American national identity may be constructed in different ways and may rely extensively on narratives of war, victory, freedom and fear in comparison with narratives of fighting indolence and social injustice (Aughey, 2010) or repression and self-determination (Zabalo, Soto, \& Mateos, 2012). Recognising the importance of different narrative approaches would support a greater understanding of the role of both targeting and marketing in building a national identity. 


\section{References}

Akaka, M. A., \& Chandler, J. D. (2011). Roles as resources: A social roles perspective of change in value networks. Marketing Theory, 11(3), 243-260. doi:10.1177/1470593111408172.

Anderson, B. (1991). 1991: Imagined Communities: Reflections on the Origin and Spread of Nationalism. Revised Edition. London and New York: Verso.

Arnould, E., \& Thompson, C. (2005). Consumer culture theory (CCT): Twenty years of research. Journal of Consumer Research, 31(4), 868-882. doi:10.1086/426626.

Aughey, A. (2010). Anxiety and injustice: The anatomy of contemporary English nationalism. Nations and Nationalism, 16(3), 506-524. doi:10.1111/j.14698129.2009.00422.x.

Biran, A., Poria, Y., \& Oren, G. (2011). Sought experiences at (dark) heritage sites. Annals of Tourism Research, 38(3), 820-841. doi:10.1016/j.annals.2010.12.001.

Boje, D. M. (1991). The storytelling organization: A study of story performance in an officesupply firm. Administrative Science Quarterly, 36(1), 106-126. doi:10.2307/2393432.

Booker, C. (2005). The seven basic plots: Why we tell stories. London, UK: Continuum Books.

Brodie, R. J., Hollebeek, L. D., Jurić, B., \& Ilić, A. (2011). Customer engagement: Conceptual domain, fundamental propositions, and implications for research. Journal of Service Research, 14(3), 252-271. doi:10.1177/1094670511411703.

Bruner, J. (2002). Making stories: Law, literature, life. New York, NY: Farrar, Strauss \& Giroux.

Bryman, A., \& Burgess, R. G. (1994). Analysing qualitative data. London, UK: Routledge.

Carr, N. (1999). A study of gender differences: Young tourist behaviour in a UK coastal resort. Tourism Management, 20(2), 223-228. doi:10.1016/S0261-5177(98)00087-9. 
Cary, S. H. (2004). The tourist moment. Annals of Tourism Research, 31(1), 61-77. doi:10.1016/j.annals.2003.03.001.

Christie, J. R. R., \& Orton, F. (1988). Writing a text on the life. Art History, 11(4), 543-563.

Chronis, A. (2005). Coconstructing heritage at the Gettysburg storyscape. Annals of Tourism Research, 32(2), 386-406. doi:10.1016/j.annals.2004.07.009.

Chronis, A., Arnould, E. J., \& Hampton, R. D. (2012). Gettysburg re-imagined: The role of narrative imagination in consumption experience. Consumption Markets \& Culture, 15(3), 261-286. doi:10.1080/10253866.2011.652823.

Cohen, E. H. (2011). Educational dark tourism at an in populo site: The Holocaust Museum in Jerusalem. Annals of Tourism Research, 38(1), 193-209. doi:10.1016/j.annals.2010.08.003.

Dann, G. M. S. (1981). Tourist motivation: An appraisal. Annals of Tourism Research, 8(2), 187-219. doi:10.1016/0160-7383(81)90082-7.

Dann, G. M. S. (1998). The dark side of tourism. Etudes et rapports, serie L. Aix-enProvence, France: Centre International de Recherches et d'Etudes Touristitique.

Dann, G. M. S. (2005). Children of the dark. In G. Ashworth \& R. Hartmann (Eds.), Horror and human tragedy revisited: The management of sites of atrocities for tourism (pp. 233-252). New York, NY: Cognizant.

Dunkley, R., Morgan, N., \& Westwood, S. (2011). Visiting the trenches: Exploring meanings and motivations in battlefield tourism. Tourism Management, 32(4), 860-868. doi:10.1016/j.tourman.2010.07.011.

Edensor, T. (1998). Tourists at the Taj: Performance and meaning at a symbolic site. London, UK: Routledge.

Edensor, T. (2000). National identity, popular culture and everyday life. Oxford, UK: Berg Publishers. 
Edvardsson, B., Tronvoll, B., \& Gruber, T. (2011). Expanding understanding of service exchange and value co-creation: A social construction approach. Journal of the Academy of Marketing Science, 39, 327-339. doi:10.1007/s11747-010-0200-y.

Erdem, T., Swait, J., \& Valenzuela, A. (2006). Brands as signals: A cross-country validation study. Journal of Marketing, 70(1), 34-49. doi:10.1509/jmkg.2006.70.1.34.

Goulding, C. (1999). Contemporary museum culture and consumer behaviour. Journal of Marketing Management, 15, 647-671. doi:10.1362/026725799785037003.

Grönroos, C. (2011). Value co-creation in service logic: A critical analysis. Marketing Theory, 11(3), 279-301. doi:10.1177/1470593111408177.

Guest, G., Bruce, A., \& Johnson, L. (2006). How many interviews are enough? An experiment with data saturation and variability. Field Methods, 18(1), 59-82. doi:10.1177/1525822X05279903.

Hankinson, G. (2009). Managing destination brands: Establishing a theoretical foundation. Journal of Marketing Management, 25(1-2), 97-115. doi:10.1362/026725709X410052.

Hebdige, D. (1979). Subcultures: The meaning of style. In K. Gelder \& S. Thornton (Eds.), The subcultures reader (pp. 121-131). London, UK: Routledge.

Hechter, M. (2000). Containing nationalism. Oxford: Oxford University Press.

Hede, A. M., \& Thyne, M. (2010). A journey to the authentic: Museum visitors and their negotiation of the inauthentic. Journal of Marketing Management, 26(7-8), 686-705. doi:10.1080/02672571003780106.

Hogg, M. K., \& Michell, P. C. N. (1996). Identity, self and consumption: A conceptual framework. Journal of Marketing Management, 12, 629-644. doi:10.1080/0267257X.1996.9964441. 
Hopkinson, G. C., \& Hogarth-Scott, S. (2001). "What happened was..." Broadening the agenda for storied research. Journal of Marketing Management, 17, 27-47.

Hyde, K. H., \& Harman, S. (2011). Motives for a secular pilgrimage to the Gallipoli battlefields. $\quad$ Tourism $\quad$ Management, $\quad 32(6), \quad$ 1343-1351. doi:10.1016/j.tourman.2011.01.008.

Joyce, C., Stevenson, C., \& Muldoon, O. (2013). Claiming and displaying national identity: Irish Travellers' and students' strategic use of "banal" and "hot" national identity in talk. British Journal of Social Psychology, 52(3), 450-468. doi:10.1111/j.20448309.2012.02097.x.

Kang, E. J., Scott, N., Lee, T. J., \& Ballantyne, R. (2012). Benefits of visiting a 'dark tourism' site: The case of the Jeju April 3rd Peace Park, Korea. Tourism Management, 33(2), 257-265. doi:10.1016/j.tourman.2011.03.004.

Kulkarni, S., \& Ganesh, G. (2002). Nation branding; loyalty towards the country, the state and the service brands. Brand Management, 10(3), 233-251.

Lee, R., Klobas, J., Tezinde, T., \& Murphy, J. (2010). The underlying social identities of a nation's brand. International Marketing Review, 27(4), 450-465. doi:10.1108/02651331011058608.

Lennon, J., \& Foley, M. (2000). Dark tourism: The attractions of death and disaster. Cornwall, UK: Thomson.

Liang, S. W.-J., Ekinci, Y., Occhiocupo, N., \& Whyatt, G. (2013). Antecedents of travellers' electronic word-of-mouth communication. Journal of Marketing Management, 29(56), 584-606. doi:10.1080/0267257X.2013.771204.

Linde, C. (2009). Working the past: Narrative and institutional memory. Oxford, UK: Oxford University Press. 
Lusch, R. F., Vargo, S. L., \& Tanniru, M. (2010). Service, value networks and learning. Journal of the Academy of Marketing Science, 38(1), 19-31. doi:10.1007/s11747-0080131-z.

Macdonald, S. (2006). Undesirable heritage: Fascist material culture and historical consciousness in Nuremberg. International Journal of Heritage Studies, 12(1), 9-28. doi:10.1080/13527250500384464.

McCabe, A. S. (2000). Tourism motivation process. Annals of Tourism Research, 27(4), 1049-1052. doi:10.1016/S0160-7383(99)00130-9.

McCracken, G. (Ed.) (1988). The long interview (Vol. 13). Newbury Park, CA: Sage Publications.

Mitchell, T. (2001). Making the nation: The politics of heritage in Egypt. In N. AlSayyad (Ed.), Consuming tradition, manufacturing heritage: Global norms and urban forms in the age of tourism (pp. 212-239). London, UK: Routledge.

Morris, M.W., Leung, K., Ames, D. \& Lickel, B. (1999). Views from inside and outside: Integrating Emic and Etic Insights about Culture and Justice Judgment. Academy of Management Review, 24 (4), 781-796

Mosse, G. (1975). The nationalization of the masses. New York, NY: Howard Fertig.

Mura, P. (2010). “Scary. . but I like it!” Young tourists' perceptions of fear on holiday. Journal of Tourism and Cultural Change, 8(1-2), 30-49.

Nairn, T. (1997). Faces of nationalism: Janus revisited. London, UK: Verso.

Nigbur, D., \& Cinnirella, M. (2007). National identification, type and specificity of comparison and their effects on descriptions of national character. European Journal of Social Psychology, 37(4), 672-691. doi:10.1002/ejsp.382.

Olins, W. (2001). Branding the nation-The historical context. Brand Management, 9(4-5), $241-248$. 
Palmer, C. (2005). An ethnography of Englishness: Experiencing identity through tourism. Annals of Tourism Research, 32(1), 7-27. doi:10.1016/j.annals.2004.04.006.

Park, H. Y. (2010). Heritage tourism: Emotional journeys into nationhood. Annals of Tourism Research, 37(1), 116-135. doi:10.1016/j.annals.2009.08.001.

Peñaloza, L. (2000). The commodification of the American west: Marketers' production of cultural meanings at the trade show. Journal of Marketing, 64(4), 82-109. doi:10.1509/jmkg.64.4.82.18073.

Podoshen, J. S. (2013). Dark tourism motivations: Simulation, emotional contagion and topographic comparison. Tourism Management, 35, 263-271.

Polanyi, L. (1982). Linguistic and social constraints on storytelling. Journal of Pragmatics, 6, 509-524. doi:10.1016/0378-2166(82)90023-6.

Prahalad, C. K., \& Ramaswamy, V. (2004). The future of competition: Co-creating unique value with consumers. Cambridge, MA: Harvard Business School Press.

Pretes, M. (2003). Tourism and nationalism. Annals of Tourism Research, 30(1), 125-142. doi:10.1016/S0160-7383(02)00035-X.

Reisinger, Y., \& Mavondo, F. (2002). Determinants of youth travel markets' perceptions of tourism destinations. Tourism Analysis, 7(1), 55-66. doi: $10.3727 / 108354202129687688$.

Richard, J. E., \& Zhang, A. (2012). Corporate image, loyalty, and commitment in the consumer travel industry. Journal of Marketing Management, 28(5-6), 568-593. doi:10.1080/0267257X.2010.549195.

Ricoeur, P. (1961). Universal civilization and national cultures: History and truth. Evanston, IL: Northwestern University.

Riessman, C. K. (1991). Beyond reductionism: narrative genres in divorce accounts. Journal of Narrative and Life History, 1, 41-68. 
Schau, H. J., Muñiz, A. M., Jr., \& Arnould, E. J. (2009). How brand community practices create value. Journal of Marketing, 73(September), 30-51.

Schembri, S. (2009). Reframing brand experience: The experiential meaning of HarleyDavidson. Journal of Business Research, 62(12), 1299-1310. doi:10.1016/j.jbusres.2008.11.004.

Seaton, A. V. (1996). Guided by the dark: From thanatopsis to thanatourism. International Journal of Heritage Studies, 2(4), 234-244. doi:10.1080/13527259608722178.

Seaton, A. V., \& Lennon, J. J. (2004). Thanatourism in the early 21 st century: Moral panics, ulterior motives and alterior desires. In T. V. Singh (Ed.), New horizons in tourism: Strange experiences and stranger practices (pp. 63-82). Oxford, UK: CAB International Books.

Shankar, A., Elliott, R., \& Goulding, C. (2001). Understanding consumption: Contributions from a narrative perspective. Journal of Marketing Management, 17, 429-453.

Sharpley, R. (2009). Shedding light on dark tourism: An introduction. In R. Sharpley \& P. R. Stone (Eds.), The darker side of travel: The theory and practice of dark tourism (pp. 3-22). Bristol: Channel View Publications.

Sharpley, R., \& Stone, P. R. (Eds.) (2009). The darker side of travel: The theory and practice of dark tourism, channel view publications, aspect of tourism (pp. 3-22). Bristol: Channel View Publications.

Simmons, A. (2001). The story factor: inspiration, influence and persuasion through the art of storytelling. New York, NY: Basic Books.

Skinner, H. (2008). The emergence and development of place marketing's confused identity. Journal of Marketing Management, 24(9-10), 915-928. doi:10.1362/026725708X381966. 
Smith, A. (1996). The origins of nations. In G. Eley \& R. G. Suny (Eds.), Becoming national: A reader (pp. 106-131). New York, NY: Oxford University Press.

Spiggle, S. (1994). Analysis and interpretation of qualitative data in consumer research. Journal of Consumer Research, 21(3), 491-503. doi:10.1086/209413.

Spillman, L. (1997). Nation and commemoration: Creating national identities in the United States and Australia. Cambridge, UK: Cambridge University Press.

Stone, P. R. (2006). A dark tourism spectrum: Towards a typology of death and macabre related tourist sites, attractions and exhibitions. Tourism: An Interdisciplinary International Journal, 54(2), 145-160.

Stone, P., \& Sharpley, R. (2008). Consuming dark tourism: A thanatological perspective. Annals of Tourism Research, 35(2), 574-595. doi:10.1016/j.annals.2008.02.003.

Thompson, C. J., \& Hirschman, E. C. (1995). Understanding the socialized body: A poststructuralist analysis of consumer's self-conceptions, body images, and self-care practices. Journal of Consumer Research, 22(2), 139-153. doi:10.1086/209441.

Uriely, N. (2005). The tourist experience: Conceptual developments. Annals of Tourism Research, 32(1), 199-216. doi:10.1016/j.annals.2004.07.008.

Vargo, S. L., \& Lusch, R. F. (2008). Service-dominant logic: Continuing the evolution. Journal of the Academy of Marketing Science, 36(1), 1-10. doi:10.1007/s11747-0070069-6.

Yngfalk, A. (2013). "It's not us, it's them!" - Rethinking value cocreation among multiple actors. Journal of Marketing Management, 29(9-10), 1163-1181.

Zabalo, J., Soto, I., \& Mateos, T. (2012). The right to self-determination and Basque nationalism: A polyvalent debate. Ethnopolitics, 11(3), 318-340. doi:10.1080/17449057.2010.500212. 